\title{
Efektivitas Model Pembelajaran Treffinger dalam Menumbuhkan Keterampilan Berpikir Kreatif Peserta Didik Sekolah Dasar
}

\author{
Sabina Ndiung ${ }^{1 *}$, Eliterius Sennen ${ }^{2}$, Arnoldus Helmon ${ }^{3}$, Mariana Jediut ${ }^{4}$ \\ 1,2,3,4 Universitas Katolik Indonesia Santu Paulus Ruteng \\ *punyaku79@gmail.com
}

\begin{tabular}{|l|l|l|l|} 
Received : 15-08-2020 & Revised: 07-10-2020 & Accepted: 22-10-2020 & Published: 05-12-2020 \\
\hline
\end{tabular}

\begin{abstract}
ABSTRAK
Penelitian ini bertujuan untuk mengetahui efektivitas model pembelajaran Treffinger dalam meningkatkan keterampilan bepikir kreatif peserta didik. Penelitian ini merupakan penelitian eksperimen dengan metode Pretest-postest control group design. Sampel penelitian adalah peserta didik kelas V SDI Watu Weri berjumlah 52 orang. Teknik pengumpulan data menggunakan tes yang terdiri atas 5 butir soal uraian dengan koefisien reliabilitas 0,79 pada kategori tinggi. Teknik analisis data yang digunakan dalam penelitian ini menggunakan teknik statistik parametrik dengan teknik pengujian hipotesisnya adalah menggunakan uji $\mathrm{t}$ independen dengan bantuan program Statistical Package for the Social Sciences (SPSS) for windows versi 23.0. Hasil penelitian menunjukkan bahwa penggunaan model pembelajaran Treffinger lebih efektif daripada model konvensional dalam meningkatkan keterampilan berpikir kreatif peserta didik kelas $\mathrm{V}$ sekolah dasar. Hal ini ditunjukkan oleh nilai $t_{\text {hitung }}$ adalah 8,772 dengan signifikansi 0,001 $<0,05$. Temuan ini tergambar secara jelas dalam langkah-langkah pembelajaran basic tools, practice with process, dan working with problem yang memuat teknik-teknik belajar kreatif. Ketiga tahapan yang tergambar dalam implementasinya mampu menuntun peserta didik menyelesaikan masalah yang bersifat non rutin.
\end{abstract}

Kata Kunci: efektivitas, keterampilan berpikir kreatif, model pembelajaran Treffinger, pembelajaran matematika

\begin{abstract}
This research aims to know the effectiveness of Treffinger's learning model in developing students' creative thinking skills. This study is a quasi-experiment with Pretest-postest control group design. The sample were fifth grade students of Watu Weri state elementary school which altogether 52 persons. Technique of collecting data used test that consisted of five items of essay test with reliability coefficient 0,79 at high category. Technique of data analysis used t-test by the assistance of a software program, namely Statistical Package for the Social Sciences (SPSS) for windows 23.0 version. Te results showed that the use of the Treffinger learning model was more effective than the conventional model in improving the creative thinking skills of grade V elementary scool students. This is indicated by the $t_{o b s}$ is 8,772 with significance of 0,001 $<0,05$. This result is obviously indicated by the stages of the instruction, such as basic tools, practice with process, and working with problem that accommodate the techniques of creative learning. Three stages stated, had been able to encourage students to solve non-routine problem.
\end{abstract}

Keywords: creative thinking skill, effectiveness, mathematics instruction, treffinger learning model 


\section{PENDAHULUAN}

Pembelajaran yang terjadi selama ini kurang memberi peluang kepada proses berpikir yang menantang nalar peserta didik dalam menyelesaikan tugas-tugas yang diberikan. Hal demikian menyebabkan peserta didik kurang terlibat secara aktif dalam menyelesaikan masalah yang mengarah pada rendahnya pencapaian prestasi akademik mereka. Pembelajaran matematika di kelas tetap menjadi persoalan yang sering diperbincangkan di dunia pendidikan sebagai dasar evaluasi kegagalan peserta didik memperoleh prestasi belajar yang maksimal (Septian, Darhim, \& Prabawanto, 2020). Pembelajaran yang hanya berfokus kemampuan hitung menghitung kurang mendukung pembentukan kemampuan pemecahan masalah (Maskur et al., 2020).

Fakta lapangan menunjukkan bahwa pembelajaran matematika di kelas cukup banyak menemui kendala diantaranya guru kurang melatih atau memberi ruang bagi peserta didik dalam memecahkan masalah yang mana peserta didik lebih banyak diarahkan menyelesaikan masalah bersifat rutin sedangkan penyelesaian pemecahan masalah non rutin kurang diperhatikan. Hal ini sejalan dengan pendapat Arends yang mengatakan bahwa dalam mengajar guru selalu menuntut peserta didik belajar dan jarang memberikan pelajaran tentang cara peserta didik untuk belajar, guru juga menuntut peserta didik menyelesaikan masalah, tapi jarang mengajarkan peserta didik tentang cara menyelesaikan masalah (Arends, 2013; Fatwa, Septian, \& Inayah, 2019).

Potret prestasi akademik peserta didik Indonesia hingga kini masih menempati peringkat rendah dunia. Persoalan tersebut relevan dengan hasil studi yang dilakukan oleh Organisation for Economic Cooperation and Development (OECD) dengan menggunakan standar Global yang lebih luas menggunakan tes Program for International Student Assessment (PISA) tahun 2015, yaitu studi yang memfokuskan pada literasi bacaan, matematika, dan IPA, menunjukkan Indonesia menduduki peringkat 69 dari 76 negara (Schleicher, 2016). Sementara (PISA) tahun 2018 yang diikuti oleh 79 negara, peserta didik Indonesia berada pada peringkat yang kurang memuaskan yang cenderung stagnan dalam 10-15 tahun terakhir. Hasil studi menunjukkan bahwa kemampuan Literasi berada pada peringkat 72 dari 77 negara, Matematika berada di peringkat 72 dari 78 negara, dan Sains berada pada peringkat 70 dari 78 negara hal ini membuat Indonesia berada pada peringkat 74 (OECD, 2019). Berdasarkan laporan terbaru tersebut, performa Indonesia cenderung menurun jika dibandingkan dengan laporan PISA 2015 (Septian \& Komala, 2019). 
Inovasi terhadap pembelajaran khususnya perhatian terhadap pengembangan kreativitas masih relatif rendah. Padahal, kreativitas merupakan komponen penting dalam pembelajaran yang membantu individu menyelesaikan masalah dalam kehidupan seharihari (Saavedra \& Opfer, 2012). Torrance (Scott, 2015) mengaitkan kreativitas dengan komitmen moral, kepercayaan diri, kemampuan melihat masalah dari sudut pandang berbeda, dan kemampuan menemukan solusi berbeda. Seperti halnya Mc Fee (Darminto, 2013) mengemukakan bahwa kreativitas merupakan kemampuan mendapatkan ide dan simbol baru, mengimprovisasi ide dan simbol yang telah mapan, menyusun kembali sehingga menjadi baru. Kreativitas merupakan upaya menghubungkan benda-benda atau gagasan yang sebelumnya tidak berhubungan. Dengan demikian, kreativitas mampu membentuk seseorang untuk berpikir kreatif. Berpikir kreatif merupakan salah satu jenis berpikir yang mengarahkan diperolehnya wawasan (insight) baru, pendekatan baru, perspektif baru, atau cara baru dalam memahami sesuatu (Runisah, Herman, \& Dahlan, 2016).

Adapun komponen keterampilan berpikir kreatif, yaitu kefasihan, fleksibilitas, dan orisinalitas (Alfuhaigi, 2015; Sriwongchai, Jantharajit, \& Chookhampaeng, 2015). Kelancaran merujuk pada kemudahan untuk menghasilkan banyak ide selama proses kreatif. Fleksibilitas merujuk kemampuan untuk meninggalkan cara berpikir lama dan mengadopsi ide-ide atau cara berpikir baru. Fleksibilitas juga ditunjukkan oleh beragamnya ide yang dikembangkan. Sedangkan orisinalitas merujuk pada kemampuan untuk menghasilkan ide-ide yang tidak biasa (unpredictable) atau unik. Kreativitas dan inovasi akan semakin berkembang jika peserta didik memiliki kesempatan untuk berpikir divergen (Scott, 2015).

Efektivitas pembelajaran merupakan ukuran keberhasilan dari suatu proses interaksi antar peserta didik maupun antara peserta didik dengan guru dalam situasi edukatif untuk mencapai tujuan pembelajaran (Kaasila \& Pehkonen, 2014; Septian, Suwarman, Monariska, \& Sugiarni, 2020). Untuk mencapai suatu konsep pembelajaran yang efektif dan efisien perlu adanya hubungan timbal balik antara peserta didik dan guru untuk mencapai suatu tujuan secara bersama, menyediakan lingkungan belajar yang aman, mendorong respons peserta didik, memiliki penguasaan konten pembelajaran, memantau kemajuan dan umpan balik belajar peserta didik, dan membangun hubungan yang positif. Hal ini sejalan dengan pandangan Vygostsky yang mengatakan bahwa pembelajaran terjadi saat peserta didik bekerja menangani tugas-tugas yang belum dipelajari namun tugas-tugas 
itu berada dalam zone of proximal development (ZPD) mereka (Rohaendi \& Laelasari, 2020; Shabani, Khatib, \& Ebadi, 2010).

Model pembelajaran yang baik adalah model pembelajaran yang mampu menuntun peserta didik menyelesaikan masalah khususnya masalah matematika (Tsany, Septian, \& Komala, 2020). Keberhasilan penguasaan suatu konsep hanya akan diperoleh jika peserta didik memiliki kemampuan berpikir tingkat tinggi, karena konsep yang telah dipahami akan melekat dalam ingatan peserta didik dalam waktu yang lama, sehingga penting sekali bagi peserta didik untuk memiliki keterampilan berpikir tingkat tinggi (Ndiung \& Jediut, 2020). Salah satu model pembelajaran yang mampu meningkatkan keterampilan berpikir kreatif pada soal-soal berpikir tingkat tinggi yang bersifat non rutin adalah model pembelajaran Treffinger.

Langkah-langkah pembelajaran Treffinger disusun dalam tiga tingkatan yaitu tahap basic tools, tahap practice with process, dan tahap working with real problem berisi teknik-teknik belajar kreatif (Nisa, 2011; Nurjanah, 2019). Selanjutnya, langkah-langkah penting dalam pembelajaran model pembelajaran Treffinger adalah 1) mengakomodasi aneka gagasan baru dan melihat sebanyak-banyaknya cara memecahkan masalah; 2) menggunakan gagasan kreatif yang melibatkan proses pemikiran dan perasaan; 3) menggunakan perasaan dan pemikiran kreatif tersebut untuk pemecahan masalah (Darminto, 2013).

Penggunaan model Treffinger dalam pembelajaran telah didukung oleh banyak hasil penelitian, diantaranya penelitian yang dilakukan oleh (Alfiyanti \& Darminto, 2016; Darminto, 2013) yang menyimpulkan bahwa penerapan model pembelajaran Treffinger signifikan mempengaruhi peningkatan kemampuan pemecahan masalah matematis. Seperti halnya penelitian (Rohaeti, Priatna, \& Dedy, 2013) yang menyimpulkan bahwa pembelajaran Treffinger dapat berkontribusi positif terhadap pengembangan atau peningkatan hasil belajar matematika peserta didik dan kemampuan pemecahan masalah matematika. Seperti halnya dengan hasil penelitian (Ndiung, Dantes, Ardana, \& Marhaeni, 2019) menunjukkan pembelajaran dengan mengimplementasikan model pembelajaran Treffinger berpendekatan PMR dengan kovariabel kemampuan numerik dapat meningkatkan keterampilan berpikir kreatif peserta didik sekolah dasar. Selain itu, penelitian dari (Nurjanah, 2019) menunjukkan bahwa penggunaan model pembelajaran Treffinger dapat meningkatkan keterampilan komunikasi dan kepercayaan diri siswa. Dengan demikian, melalui penerapan model Treffinger dalam pembelajaran matematika di sekolah dasar diharapkan mampu meningkatkan keterampilan bepikir kreatif peserta didik. 


\section{METODE PENELITIAN}

Penelitian ini merupakan penelitian eksperimen dengan desain Pretest-postes control group design. Dalam desain ini, sebelum diberi perlakuan sampel diukur terlebih dahulu keterampilan berpikir kreatifnya dengan pretes kemudian setelah diberikan perlakuan diukur lagi dengan postes. Kelompok eksperimen mengikuti pembelajaran matematika dengan model pembelajaran Treffinger sedangkan kelompok kontrol mengikuti pembelajaran matematika dengan model pembelajaran konvensional.

Sampel penelitian adalah SDI Watu Weri berjumlah 52 orang peserta didik yang terdiri dari dua rombongan belajar yaitu kelas VA dan kelas VB dengan masing-masing kelas berjumlah 26 orang peserta didik. Kelas VA adalah kelompok Eksperimen sedangkan kelas VB kelompok kontrol. Selama perlakuan peserta didik menyelesaikan masalah baik secara individu maupun kelompok menggunakan LKPD pada materi operasi hitung pecahan.

Untuk rubrik penilaian diadaptasi dari Bosch (La Moma, 2015) dengan skala 0-4. Berdasarkan jenis data, maka data dalam penelitian ini dikumpulkan dengan menggunakan metode tes. Data mengenai keterampilan berpikir kreatif peserta didik dikumpulkan dengan tes keterampilan berpikir kreatif. Instrumen tes yang digunakan telah divalidasi oleh 5 orang pakar dari Universitas Pendidikan Ganesha (Undiksha) Singaraja yang memiliki keahlian dalam bidang bahasa, matematika, evaluasi, dan psikologi. Instrumen tes yang digunakan telah dilakukan uji validitas dan reliabilitas butir. Jumlah soal tes keterampilan berpikir kreatif berjumlah 5 butir soal uraian. Analisis data yang digunakan dalam penelitian ini menggunakan uji-t yang didahului dengan uji asumsi yaitu uji normalitas sebaran data dan uji homogenitas varians kelompok data menggunakan bantuan program Statistical Package for the Social Sciences (SPSS) for windows versi 23.0.

\section{HASIL DAN PEMBAHASAN}

Sebelum diberikan perlakuan, penelitian ini diawali dengan pemberian pretes tentang keterampilan berpikir kreatif pada kelompok eksperimen dan kelompok kontrol. Hasil pretes dari kedua kelompok tersebut disajikan pada Tabel 1.

Tabel 1. Data Skor Pretes Keterampilan Berpikir kreatif

\begin{tabular}{lllcccccc}
\hline Group & $\mathrm{N}$ & Mean & Median & Stand.Dev. & Var & Range & Min & Max \\
\hline Eksperimen & 26 & 46,35 & 47,5 & 11,59 & 134,32 & 41 & 24 & 65 \\
Kontrol & 26 & 45,30 & 46,0 & 10,50 & 110,28 & 38 & 24 & 62 \\
\hline
\end{tabular}


Berdasarkan data pada Tabel 1, dapat dikatakan bahwa kondisi awal kelas eksperimen dan kelas kontrol berdasarkan rata-rata kelas tidak berbeda secara signifikan. Selanjutnya, dilakukan analisis uji normalitas dan homogenitas varians kelompok data. Berdasarkan hasil pengujian normalitas data diperoleh $0,200>0,05$, dengan demikian data pretes keterampilan berpikir kreatif peserta didik berdistribusi normal. Pengujian homogenitas varian kelompok data diperoleh bahwa sig. 0, $261>0,05$, dengan demikian dapat dikatakan bahwa kedua kelompok memiliki varian yang homogen. Setelah diberikan perlakuan maka kedua kelompok tersebut diberikan postes terkait keterampilan berpikir kreatif. Hasil perhitungan ukuran pemusatan data skor postes keterampilan berpikir kreatif disajikan pada Tabel 2.

Tabel 2. Data Skor Postes Keterampilan Berpikir Kreatif

\begin{tabular}{llccccccc}
\hline Group & N & Mean & Median & Stand.Dev. & Var & Range & Min & Max \\
\hline Eksperimen & 26 & 66,42 & 65,00 & 9,92 & 98,49 & 32 & 49 & 81 \\
Kontrol & 26 & 62,15 & 63,35 & 9,10 & 82,86 & 41 & 35 & 76 \\
\hline
\end{tabular}

Berdasarkan data pada Tabel 2, diperoleh mean skor kelompok ekspeimen yaitu kelas yang meneapakan model pembelajaran Treffinger lebih tinggi dibandingkan dengan mean skor kelompok kontrol yang menggunakan model konvensional. Selanjutnya dilakukan analisis normalitas sebaran data dan uji homogenitas varians kelompok. Berdasarkan hasil pengujian diperoleh angka signifikansi Kolmogorov Smirnov yaitu 0,080 $>0,05$, sehingga dapat dikatakan bahwa kelompok data skor keterampilan berpikir kreatif berasal dari populasi yang berdistribusi normal dan untuk pengujian homogenitas varian kelompok data diperoleh $0,910>0,05$, maka dapat dikatakan bahwa data posttest kelas kontrol dan kelas eksperimen berasal dari varian yang homogen. Selanjutnya, pengujian hipotesis menggunakan uji-t independent. Berdasarkan hasil analisis diperoleh sig $<0,05$, yaitu $0,001<0,05$, artinya bahwa model pembelajaran Treffinger lebih efektif dalam meningkatkan keterampilan berpikir kreatif peserta didik daripada model pembelajaran konvensional.

Setelah dilakukan proses pembelajaran dengan menggunakan model pembelajaran Treffinger pada kelas eksperimen dan pada kelas kontrol menggunakan model pembelajaran konvensional, ternyata memberikan pengaruh yang signifikan. Hasilnya terlihat pada Tabel 3 dengan rerata posttest kelas eksperimen 66,42 sedangkan rerata posttest pada kelas kontrol adalah 62,15 . Hal ini menunjukkan ada perubahan skor sebelum 
dan setelah diberikan perlakuan. Selanjutnya rata-rata N-Gain dari hasil pretest dan posttest dapat dilihat pada Tabel 3. Untuk hasil rekapitulasi N-Gain dapat dilihat pada Tabel 3.

Tabel 3. Rata-rata N-Gain

\begin{tabular}{lcccccc}
\hline \multicolumn{1}{c}{ Group } & $\mathrm{N}$ & \multicolumn{4}{c}{ Nilai } & Interpretasi \\
\cline { 3 - 6 } & & $\begin{array}{c}\text { Skor } \\
\text { Ideal }\end{array}$ & $\begin{array}{c}\text { Nilai } \\
\text { Minimum }\end{array}$ & $\begin{array}{c}\text { Nilai } \\
\text { Maksimum }\end{array}$ & $\begin{array}{c}\text { Rerata } \\
\text { N-Gain }\end{array}$ & N-Gain \\
\hline Eksperimen & 26 & 100 & 0,15 & 0,64 & 0,38 & Sedang \\
\hline Kontrol & 26 & 100 & 0,14 & 0,57 & 0,3 & Sedang \\
\hline
\end{tabular}

Berdasarkan data pada Tabel 3, dapat dikatakan bahwa N-Gain pada kelas eksperimen lebih tinggi dibandingkan dengan N-Gain pada kelas kontrol. Perbandingan hasil data N-Gain kelas eksperimen dengan kelas kontrol dapat dilihat pada Gambar 1.

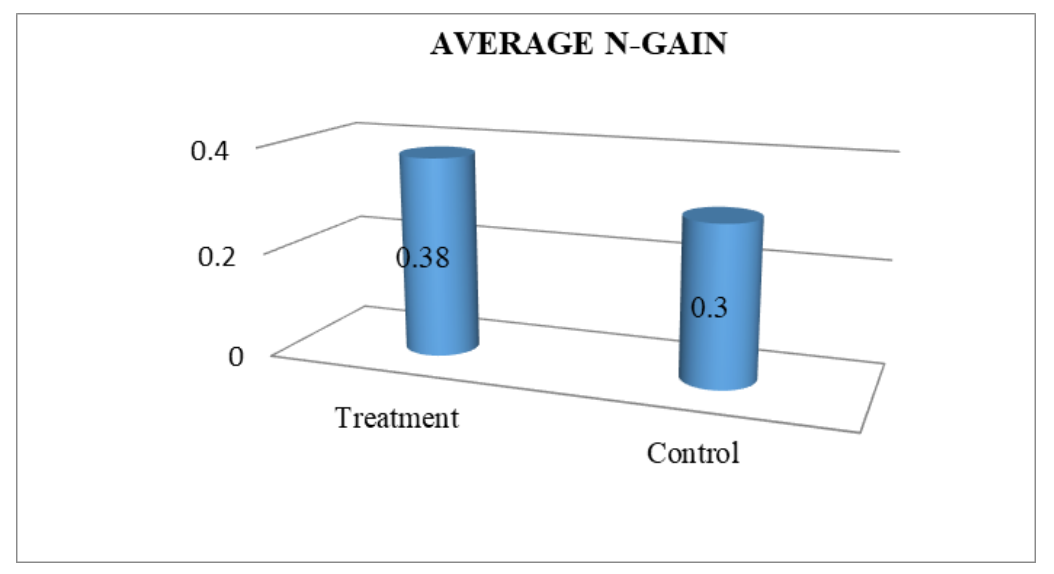

Gambar 1. Diagram Rerata N-Gain

Berdasarkan Gambar 1, dapat dilihat rerata N-Gain kelas eksperimen lebih tinggi dibandingkan dengan rerata N-Gain kelas kontrol. Rerata N-Gain untuk kelas eksperimen adalah 0,38 sedangkan rerata $\mathrm{N}$-Gain kelas kontrol adalah 0,30, kriteria Gain ternormalisasi berada pada kategori sedang. Selanjutnya, uji normalitas N-Gain diperoleh $0,151>0,05$ untuk kelas eksperimen dan nilai 0,173>0,05 untuk kelas kontrol. Hal ini berarti data pada kelas eksperimen dan kelas kontrol berdistribusi normal. Pengujian homogenitas data $\mathrm{N}$-Gain diperoleh 0,095 > 0,05, maka dapat dikatakan bahwa data $\mathrm{N}$ Gain kelas kontrol dan kelas eksperimen berasal dari varian yang homogen. Setelah memenuhi uji asusmsi maka dilanjutkan dengan uji-t. Hasil uji-t data N-Gain pada level signifikan 0,05, diperoleh Asymp. Sig. (2-tailed) < 0,05. yaitu 0,001<0,05, Hal ini berarti bahwa ada perbedaan keterampilan berpikir kreatif peserta didik yang mengikuti pembelajaran dengan model pembelajaran Treffinger dengan peserta didik yang mengikuti pembelajaran dengan model pembelajaran konvensional. 
Temuan penelitian menunjukkan bahwa penggunaan model pembelajaran Treffinger lebih efektif daripada model konvensional dalam meningkatkan keterampilan berpikir kreatif peserta didik kelas $\mathrm{V}$ sekolah dasar. Hal ini ditunjukkan oleh nilai $\mathrm{t}$ hitung adalah 8,772 dengan signifikansi $0,001<0,05)$. Hasil penelitian ini didukung oleh penelitiannya (Ndiung et al., 2019) yang menunjukkan bahwa penerapan model pembelajaran kreatif Trefingger dapat meningkatkan keterampilan bepikir kreatif dengan kovariabel kemampuan numerik.

Adapun tiga tahapan model pembelajaran Treffinger yaitu tahap basic tools, tahap practice with process, dan tahap working with real problems. Pada tahap basic tools, pada tahap ini peserta didik dihadapkan dengan contoh masalah riil sesuai dengan pengalaman dan tingkat pengetahuannya sehingga peserta didik segera terlibat dalam pelajaran secara bermakna dengan memberi lebih dari satu penyelesaian. Disini, dalam menyelesaikan permasalahan tersebut secara individu dengan maksud mereka segera terlibat dalam penyelesaian masalah dan mampu menghasilkan banyak gagasan dalam menyelesaikan masalah. Pada tahap ini peserta didik dipacu untuk berpikir lebih dari biasanya sehingga mampu melahirkan gagasan yang variatif. Sebagai contoh, sebagian besar $(80,76 \%)$ peserta didik dapat menentukan operasi hitung pecahan melalui soal-soal yang bersifat realistik. Pembiasaan aktivitas pada tahap basic tools mampu menuntun peserta didik pada keterampilan berpikir kreatif aspek fluency atau kefasihan. Hal ini juga ditampilkan oleh peserta didik dalam menyelesaikan soal-soal tes keterampilan berpikir kreatif dapat menampilkan hasil pekerjaan yang baik sesuai dengan tingkat pemahaman mereka.

Pada tahap practice with process, peserta didik dibentuk suatu iklim pembelajaran yang interaktif sehingga mengarahkan mereka ke dalam beberapa tim untuk menyelesaikan LKPD tentang operasi hitung pecahan biasa dan pecahan campuran. Di sini, peserta didik dihadapkan dengan LKPD yang memuat soal-soal yang menantang proses bepikir kreatif yang mengukur berpikir tingkat tinggi. Peserta didik dibentuk dalam kelompok diskusi berdasarkan variasi kemampuan peserta didik yang terdiri dari 4-5 orang. Pembagian kelompok atas dasar variasi kemampuan ini dilakukan agar peserta didik dapat saling berinteraksi dan kreatif mengkomunikasikan ide atau gagasan mereka tentang penyelesaian masalah matematis. Sejalan dengan penelitiannya (Septian \& Komala, 2019) menunjukkan bahwa pembelajaran dengan model pembelajaran yang sesuai mampu meningkatkan kemampuan berpikir kreatif matematis siswa seperti halnya model pembelajaran creative problem solving (CPS). Dengan bekal kemampuan dan pemahaman konsep yang baik 
mampu mengurangi kesalahan peserta didik dalam menyelesaikan masalah ataupun dalam menyelesaikan soal matematika yang terkategori sulit (Sennen, Ndiung, \& Supardi, 2016).

Selama aktivitas pembelajaran menggunakan metode diskusi berkelompok, peserta didik saling berinteraksi dan terlibat aktif dalam menyelesaikan masalah yang berkaitan dengan pecahan. Peserta didik saling mengkomunikasikan idenya dan saling menghargai perbedaan pendapat, selain itu peserta didik yang kurang mampu dapat bertanya kepada temannya yang lebih mampu dan ketika permasalahan tak terselesaikan, dengan segera mereka mengkomunikasikannya dengan guru.

Hasil penelitian ini berkaitan dengan teori Vygotsky yaitu pembelajaran dilakukan dengan ZPD dimana anak belajar kelompok kerja kreatif sehingga memudahkan untuk mengerti dengan cepat, dengan interaksi sosial dengan teman sebaya, anak mudah paham. Guru sebagai scaffolding dan guru mengurangi bantuannya itu sampai siswa bisa mandiri dan mengerti sendiri. Pembelajaran dengan tutor sebaya, siswa bisa tukar pikiran untuk memecahkan masalah yang kompleks sehingga menghasilkan atau dapat menarik kesimpulan dan menjadi pengetahuan (Rohaendi \& Laelasari, 2020; Sze Yeng \& Hussain, 2010). Dengan demikian, apabila peserta didik selalu diberi kesempatan untuk menyelesaikan masalah sendiri dengan cara mereka sendiri maka bukan tidak mungkin mereka akan terbiasa melakukan hal-hal yang luar biasa yang tidak pernah terpikirkan oleh orang lain. Kegiatan pembelajaran dengan melibatkan peserta didik secara aktif, menghubungkan permasalahan realistik dengan konsep yang sedang dipelajari dapat membantu peserta didik menyimpan pengetahuan dalam memori jangka panjang. Melalui aktivitas pembelajaran pada tahap ini mampu menuntun peserta didik pada aspek originalitas.

Pada tahap working with real problems, guru membangun pembelajaran yang berlangsung secara interaktif yang menuntun peserta didik dapat mengkonstruksi pertanyaan serta penyelesaiannya secara mandiri ataupun kelompok dan menyelesaikan masalah realistik secara bertahap melalui proses penyelesaian masalah secara informal menuju penyelesaian masalah yang bersifat formal. Dalam hal ini suatu permasalahan yang dibuat oleh peserta didik dapat diselesaikan dengan berbagai kemungkinan penyelesaian mulai dari menggunakan gambar, menggunakan pola, menyamakan penyebut. Pada tahap ini, dapat membantu peserta didik tidak sekadar menyelesaikan masalah, tetapi apa yang dipelajari bermakna dan dapat disimpan pada memori jangka panjang. Setelah peserta didik mampu menyelesaikan masalah dengan benar, selanjutnya mereka mendapatkan penghargaan dari guru berupa penguatan atau lainnya yang memacu motivasi belajar 
matematika. Pembiasaan aktivitas pada tahapan ini, dapat membantu peserta didik secara luwes menyampaikan hasil kerja mereka dengan cara yang mereka gunakan dalam menyelesaikan tugas yang diberikan. Mereka juga mampu menampilkan cara lain dari penyelesaian masalah tanpa tuntunan guru tetapi melalui interaksi dengan teman kelompoknya yang lebih mampu. Peserta didik sudah mampu menyelesaikan masalah secara bertahap mulai dari tingkat sederhana ke tingkat yang kompleks (Septian \& Rizkiandi, 2017).

Pembiasaan aktivitas pembelajaran pada tahap working with real problems, mampu mengarahkan peserta didik pada pemeahan masalah yang bersifat non rutin. Dari tahapan pelaksanaan pembelajaran matematika melalui model pembelajaran Treffinger dapat menuntun peserta didik menyelesaikan masalah secara kreatif yang mana pengalaman ini tidak mereka dapatkan sebelumnya, karena selalu menampilkan soal-soal cerita yang bersifat rutin yang tidak memerlukan pemikiran lebih lanjut untuk menyelesaikannya. Di sini, peserta didik menyelesaikan masalah dengan baik karena mereka memiliki kemampuan yang baik tentang operasi hitung dasar dan operasi hitung pecahan. Dari uraian tersebut jelaslah bahwa untuk dapat menguasai materi matematika, seorang peserta didik harus menguasai beberapa kemampuan dasar lebih dahulu. Setelah itu, peserta didik harus mampu mengaitkan antara pengetahuan yang baru dengan pengetahuan yang sudah dipunyainya. Di samping itu, seorang guru dituntut untuk mengecek, mengingatkan kembali ataupun memperbaiki pengetahuan prasyarat peserta didiknya sebelum ia memulai membahas topik baru, sehingga pengetahuan yang baru tersebut dapat berkait dengan pengetahuan yang lama yang lebih dikenal sebagai belajar bermakna (meaningful learning). Temuan ini didukung oleh penelitian yang dilakukan oleh (Kurniati, 2018) yang menunjukkan bahwa untuk mengembangkan keterampilan berpikir kreatif dapat dilakukan melalui aktivitas pembelajaran dengan menerapkan pendekatan ataupun media atau alat peraga yang menarik yang mampu mendorong peserta didik antusias dan senang mengikuti pembelajaran. Pembiasaan aktivitas pembelajaran pada tahap working with real problems mampu menumbuhkan keterampilan berpikir kreatif peserta didik pada aspek fleksibilitas.

\section{KESIMPULAN}

Berdasarkan hasil penelitian dan pembahasan, temuan penelitian ini menunjukkan bahwa penerapan model pembelajaran Treffinger lebih efektif dalam meningkatkan keterampilan berpikir kreatif daripada model pembelajaran konvensional bagi peserta didik kelas V sekolah dasar. Melalui penerapan tiga langkah model pembelajaran Treffinger 
mampu menuntun peserta didik pada aspek kefasihan, fleksibilitas dan originalitas. Hal ini dapat dilihat dari hasil analisis statistik deskriptif yang menunjukkan adanya perbedaan yang signifikan antara peserta didik yang diajarkan dengan menggunakan model pembelajaran Treffinger dan model pembelajaran konvensional. Sehingga simpulan penelitian ini adalah penggunaan model pembelajaran Treffinger lebih efektif dalam meningkatkan keterampilan berpikir kreatif peserta didik sekolah dasar terlebih khusus dalam menyelesaikan masalah pecahan. Dengan demikian dapat dikatakan bahwa model pembelajaran Treffinger efektif diterapkan dalam pembelajaran matematika di sekolah dasar khususnya pada materi operasi hitung pecahan.

\section{REFERENSI}

Alfiyanti, D., \& Darminto, B. P. (2016). Pengaruh model pembelajaran Treffinger terhadap kreativitas matematis kelas VII SMP Negeri 1 Poncowarno. 82-87.

Alfuhaigi, S. S. (2015). School Environment and Creativity Development: a Review of Literature. Journal of Educational and Instructional Studies in the World, 5(2), 3338.

Arends, R. I. (2013). Learning to teach (9th ed.). Copyright (C) by McGraw-Hill Education.

Darminto, B. P. (2013). Improving the Ability of Students' Mathematical Problem Solving. Jurnal Pendidikan Matematika Dan Sains Tahun, 1(2), 101-107.

Fatwa, V. C., Septian, A., \& Inayah, S. (2019). Kemampuan Literasi Matematis Siswa melalui Model Pembelajaran Problem Based Instruction. Mosharafa: Jurnal Pendidikan Matematika, 8(3), 389-398.

Kaasila, R., \& Pehkonen. (2014). Effective mathematics teaching in Finland through the eyes of elementary student teachers. (January 2009).

Kurniati, N. (2018). Mengakses dan memonitor kemampuan berpikir kreatif matematis siswa kelas V sekolah dasar dalam pembelajaran matematika. Jurnal Prisma, 7(1), 99-106.

La Moma. (2015). Pengembangan Instrumen Kemampuan Berpikir Kreatif Matematis. Delta-Pi: Journal Matematika Dan Pendidikan Matematika, 4(1), 27-41.

Maskur, R., Sumarno, Rahmawati, Y., Pradana, K., Syazali, M., Septian, A., \& Palupi, E. K. (2020). The effectiveness of problem based learning and aptitude treatment interaction in improving mathematical creative thinking skills on curriculum 2013. European Journal of Educational Research, 9(1), 375-383. https://doi.org/10.12973/eu-jer.9.1.375

Ndiung, S., Dantes, N., Ardana, I. M., \& Marhaeni, A. (2019). Treffinger Creative Learning Model with RME Principles on Creative Thinking Skill by Considering Numerical Ability. International Journal of Instruction, 12(3), 731-744. https://doi.org/doi:10.29333/iji.2019.12344a

Ndiung, S., \& Jediut, M. (2020). Pengembangan instrumen tes hasil belajar matematika peserta didik sekolah dasar berorientasi pada berpikir tingkat tinggi. Premiere Educandum: Jurnal Pendidikan Dasar Dan Pembelajaran Volume, 10(June), 94-111. https://doi.org/10.25273/pe.v10i1.6274

Nisa, T. F. (2011). Pembelajaran Matematika dengan Setting Model Treffinger Untuk Mengembangkan Kreativitas Siswa. Pedagogia, 1(1), 35-48.

Nurjanah, E. S. (2019). The application of treffinger learning model in improving students' 
mathematical communication skill and their confidence. Prisma, 8(2), 160-166.

OECD. (2019). PISA 2018 insights and interpretations.

Rohaendi, S., \& Laelasari, N. I. (2020). Penerapan Teori Piaget dan Vygotsky Ruang Lingkup Bilangan dan Aljabar pada Siswa Mts Plus Karangwangi. Prisma, 9(1), 65. https://doi.org/10.35194/jp.v9i1.886

Rohaeti, T. I., Priatna, B. A., \& Dedy, E. (2013). Penerapan model treffinger pada pembelajaran matematika untuk meningkatkan kemampuan berpikir kreatif siswa smp. $1(1)$.

Runisah, Herman, T., \& Dahlan, J. A. (2016). The Enhancement of Students â€ ${ }^{\mathrm{TM}}$ Creative Thinking Skills in Mathematics through The 5E Learning Cycle with Metacognitive Technique. International Journal of Education and Research, 4(7), 347-360.

Saavedra, A. R., \& Opfer, V. D. (2012). Teaching and Learning 21st century Skills. Patnership for Global Learning, (April), 1-35.

Schleicher, A. (2016). PISA.

Scott, C. L. (2015). What Kind of Pedagogies for the 21st Century? Education Research and Foresight, 15(3), 1-21.

Sennen, E., Ndiung, S., \& Supardi, K. (2016). Analisis kesalahan siswa sekolah dasar dalam menyelesaikan soal-soal matematika yang terkategori sulit pada UASBN. Jurnal Pendidikan Dan Kebudayaan Missio, 8(2), 253-268.

Septian, A., Darhim, \& Prabawanto, S. (2020). Geogebra in integral areas to improve mathematical representation ability. Journal of Physics: Conference Series, 1613(1), 12035. https://doi.org/10.1088/1742-6596/1613/1/012035

Septian, A., \& Komala, E. (2019). Kemampuan Koneksi Matematik dan Motivasi Belajar Siswa dengan Menggunakan Model Problem-Based Learning (PBL) Berbantuan Geogebra di SMP. PRISMA, 8(1), 1-13. https://doi.org/10.35194/jp.v8i1.438

Septian, A., \& Rizkiandi, R. (2017). Penerapan Model Problem Based Learning (PBL) terhadap Peningkatan Kemampuan Berpikir Kreatif Matematis Siswa. PRISMA, 6(1). https://doi.org/10.35194/jp.v6i1.22

Septian, A., Suwarman, R. F., Monariska, E., \& Sugiarni, R. (2020). Somatic , auditory , visualization, intellectually learning assisted by GeoGebra to improve student's mathematical representation skills. Journal of Physics : Conference Series, 1657(1), 12023. https://doi.org/10.1088/1742-6596/1657/1/012023

Shabani, K., Khatib, M., \& Ebadi, S. (2010). Vygotsky â $€^{\mathrm{TM}}$ s Zone of Proximal Development: Instructional Implications and Teachers $\hat{a} €^{\mathrm{TM}}$ Professional Development. English Language Teaching, 3(4), 237-248.

Sriwongchai, A., Jantharajit, N., \& Chookhampaeng, S. (2015). Developing the Mathematics Learning Management Model for Improving Creative Thinking in Thailand. International Education Studies, 8(11), 77-87. https://doi.org/10.5539/ies.v8n11p77

Sze Yeng, F., \& Hussain, R. M. R. (2010). Self-directed learning in a socioconstructivist learning environment. Procedia - Social and Behavioral Sciences, 9, 1913-1917. https://doi.org/10.1016/j.sbspro.2010.12.423

Tsany, U. N., Septian, A., \& Komala, E. (2020). The ability of understanding mathematical concept and self-regulated learning using macromedia flash professional 8. Journal of Physics: Conference Series, 1657, 12074. https://doi.org/10.1088/17426596/1657/1/012074 